\title{
Effects of microbial inoculant and fibrolytic enzymes on fermentation quality and nutritional value of BRS capiaçu grass silage
}

\author{
Efeitos do inoculante microbiano e das enzimas \\ fibrolíticas na qualidade fermentativa e no valor \\ nutricional de silagem de capim-BRS capiaçu
}

Mariana Antunes de Jesus ${ }^{1}$; Flávio Pinto Monção ${ }^{2 *}$; João Paulo Sampaio Rigueira3; Vicente Ribeiro Rocha Júnior ${ }^{3 ;}$ Virgílio Mesquita Gomes; Nelson de Abreu Delvaux Junior3; Daniel Ananias de Assis Pires;; Eleuza Clarete Junqueira de Sales;; Cinara da Cunha Siqueira Carvalho ${ }^{3}$; Alexandre Soares dos Santos ${ }^{4}$

\section{Highlights}

The inoculants increased the time for breaking the aerobic stability of the silage.

The inoculant Silotrato ${ }^{\circledR}$ reduced the concentration of butyric acid.

The inoculants did not modify the chemical composition of the BRS capiaçu silage.

\begin{abstract}
The objective of this study was to evaluate the effect of bacterial-enzymatic inoculants with different concentrations of fibrolytic enzymes on the fermentation quality and nutritional value of the silage of BRS capiaçu grass. Two bacterial-enzymatic inoculants with different levels of enzyme complex were evaluated (Silotrato ${ }^{\circledR}(5 \%)$ and Biotrato ${ }^{\circledR}(8 \%)$ ) and control silage (without additive) according to a completely randomized design with eight replicates. To evaluate the silage aerobic stability, a completely randomized split plot design was used with three treatments (plots) and seven times after opening (subplots). There was no interaction between treatments and times after opening on values of $\mathrm{pH}(\mathrm{P}=0.79)$. Regarding bacterial-enzymatic inoculants, the silage $\mathrm{pH}$ was $21.66 \%$ and $16.16 \%$ higher in silage without additive (mean of 6.00 ) compared to silage with $5 \%$ and $8 \%$ enzyme complex $(P<0.01)$. There was no difference between treatments on $\mathrm{pH}(\mathrm{P}$

1 Student of Animal Science Master's Course, State University of Montes Claros, UNIMONTES, Janaúba, MG, Brazil. E-mail: marianaantunesj@hotmail.com

2 Prof. and Researcher PNPD/Capes, Postgraduate Program in Animal Science (Master), UNIMONTES, Janaúba, MG, Brazil. E-mail: moncaomoncao@yahoo.com.br

3 Profs. Drs., Postgraduate Program in Animal Science (Master), UNIMONTES, Janaúba, MG, Brazil. E-mail: joao.rigueira@ unimontes.br; vicente.rocha@unimontes.br; virgilio.gomes@unimontes.br; nelson.junior@unimontes.br; piresdaa@ gmail.com; eleusa.sales@unimontes.br; cinara.carvalho@unimontes.br

${ }^{4}$ Prof. Dr., Federal University of the Jequitinhonha and Mucuri Valleys, UFVJM, Diamantina, MG, Brazil. E-mail: alexandre. soares@ufvjm.edu.br

* Author for correspondence
\end{abstract}

Received: Sept. 11, 2020 - Approved: Dec. 07, 2020 
$=0.08)$, lactic acid $(p=0.08)$ and acetic acid $(p=0.64)$, means of $3.11,47.31 \mathrm{~g}$ dry matter (DM)-1 and 11.19 g DM-1, respectively. There was no difference between treatments for any of the chemical composition variables $(P=0.86)$. Mean values for $D M$, crude protein, neutral detergent fiber and total digestible nutrients were $22.31 \%, 6.65 \%, 71.15 \%$ and $42.07 \%$, respectively. There was a higher concentration of butyric acid in the control silage compared to Silotrato ${ }^{\circledR}$ silage. The control silage and silage treated with Biotrato ${ }^{\circledR}$ presented effluent losses $(P=0.05) 13.99 \%$ higher than silage with Silotrato ${ }^{\circledR}$. For ensiling BRS capiaçu grass, it is recommended to use lactic acid bacteria containing $5 \%$ fibrolytic enzymes.

Key words: Inoculant. Aerobic stability. Digestibility. Indigestible fiber.

\section{Resumo}

Objetivou-se avaliar o efeito de inoculantes bacteriano-enzimáticos com diferentes concentrações de enzimas fibrolíticas sobre a qualidade fermentativa e valor nutricional da silagem de capim-BRS capiaçu. Foram avaliados dois inoculantes bacteriano-enzimáticos com diferentes níveis de complexo enzimático (Silotrato ${ }^{\circledR}(5 \%)$ e Biotrato $\left.^{\circledR}(8 \%)\right)$ e silagem controle (sem aditivo) seguindo o delineamento inteiramente casualizado com oito repetições. Para avaliação da estabilidade aeróbia da silagem foi utilizado o delineamento inteiramente casualizado em esquema de parcelas subdivididas com três tratamentos (parcelas) e sete tempos após abertura (subparcelas). Não houve interação entre tratamentos e tempos após a abertura da silagem sobre os valores de $\mathrm{pH}(\mathrm{P}=0,79)$. Em relação aos inoculantes bacteriano-enzimáticos, o pH da silagem foi $21,66 \%$ e 16,16\% maior na silagem sem aditivo (média de 6,00) em relação à silagem com $5 \%$ e $8 \%$ de complexo enzimático $(P<0,01)$. Não houve diferença entre os tratamentos quanto ao $\mathrm{pH}$ $(P=0,08)$, ácido lático $(P=0,08)$ e ácido acético $(p=0,64)$, médias de 3,$11 ; 47,31$ g matéria seca (MS)-1e 11,19 $\mathrm{gMS}^{-1}$, respectivamente. Não houve diferença entre os tratamentos para nenhuma das variáveis de composição química $(P=0,86)$. As médias para $M S$, proteína bruta, fibra em detergente neutro e nutrientes digestíveis totais foram 22,31\%, 6,65\%, 71,15\% e 42,07\%, respectivamente. Houve maior concentração de ácido butírico na silagem controle em relação à silagem com Silotrato ${ }^{\circledR}$. A silagem controle e a silagem tratada com Biotrato ${ }^{\circledR}$ apresentaram perdas por efluentes $(P=0,05) 13,99 \%$ maiores que a silagem com Silotrato ${ }^{\circledR}$. Durante a ensilagem do capim BRS capiaçu, recomenda-se o uso de bactérias lácticas contendo $5 \%$ de enzimas fibrolíticas.

Palavras-chave: Inoculante. Estabilidade aeróbica. Digestibilidade. Fibra indigestível.

\section{Introduction}

Elephant grass (Pennisetum purpureum, Schum) has been used for silage production in several regions of the world. This is because, among tropical grasses, elephant grass is a plant with high potential for

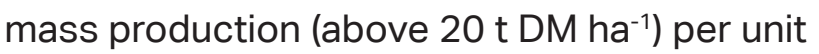
area and good nutritional value (Pereira, Lédo, \& Machado, 2017). It is a forage with lower production cost compared to other perennial and/or annual crops for silage production.

Among the elephant grass clones, the BRS capiaçu cultivar has stood out for its high mass production. According to Pereira et al. (2017) and Monção et al. (2019 a,b), the annual dry matter yield of BRS capiaçu grass varies from 50 to $72 \mathrm{t} \mathrm{ha}^{-1}$ year $^{-1}$. According to the same authors, for silage production, it is recommended to harvest BRS capiaçu 
grass between 90 and 120 days, or between 3 and 4.2 meters in height. However, at this recommended cutting age for silage, some researchers, such as Monção et al. (2019a) verified dry matter digestibility between $50.5 \%$ and $47.2 \%$ and fiber fraction of $33 \%-28 \%$. An alternative to improve forage digestibility is the use of bacterial-enzymatic inoculants. This type of inoculant contains fibrolytic enzymes (i.e., hemicellulase, xylanases and cellulase) and bacteria that produce lactic and acetic acid, mainly responsible for silage preservation.

In ruminant nutrition, fibrolytic enzymes are used to improve fiber degradability and, consequently, the digestible energy intake by the animal (Bureenok et al., 2019). In fact, enzymes, such as hemicellulases, xylanases and cellulases can be converted into sugars (Khota, Pholsen, Higgs, \& Cai, 2016), making substrate available for fermentation. Thus, it appears that fibrolytic enzymes can also be applied during the ensiling process. Several authors (Sun et al., 2012; Khota et al., 2016; Desta, Yuan, Li, \& Shao, 2016; Bureenok et al., 2019) have already reported the potential of fibrolytic enzymes to improve silage quality. According to Bureenok et al. (2019), the improvement in digestibility, mainly the fiber fraction of the forage, using bacterialenzymatic inoculant is more expressive when there is a high content of soluble carbohydrates in the ensiled mass. Therefore, it can be supposed that the combination of homo- and heterofermentative bacteria and fibrolytic enzymes in the inoculant may improve the preservation and nutrient availability of the ensiled mass of BRS capiaçu grass. Currently, there is no information available on the fermentation of BRS capiaçu grass silage and its digestibility when treated with bacterial-enzymatic inoculants with different concentrations of fibrolytic enzymes.
Based on the above, the objective was to evaluate the effect of bacterial-enzymatic inoculants with different concentrations of fibrolytic enzymes on the fermentation quality and nutritional value of BRS capiaçu grass silage.

\section{Materials and Methods}

All animal care and handling procedures were approved by the Ethics committee on animal use of the State University of Montes Claros (Unimontes), Brazil (protocol CEBEAUnimontes 175/2018).

On November 13, 2019, an area $\left(\sim 100 \mathrm{~m}^{2}\right)$ implemented in 2017 with capiaçu BRS grass (Pennisetum purpureum Schum; 1.2 meters between lines) at Experimental farm of the Unimontes, Janaúba (geographical coordinates: $15^{\circ} 52^{\prime} 38^{\prime \prime S}, 43^{\circ} 20^{\prime} 05^{\prime \prime} \mathrm{W}$ ), was managed for cutting and silage production. The climate of the region, according to the classification of Köppen- Geiger, is Aw, with summer rains and well-defined periods of drought in winter. The average annual rainfall is $800 \mathrm{~mm}$, with an average annual temperature of $24{ }^{\circ} \mathrm{C}$. The climate is tropical mesothermal, due to the altitude, sub-humid and semi-arid, with irregular rains, causing long periods of drought.

After uniform cutting of forage on November 13, 2019, two tones bovine manure (pH - 8.4; $217 \mathrm{~g}$ moisture, $488 \mathrm{~g}$ dry matter, 11 $\mathrm{g} \mathrm{kg}^{-1}$ nitrogen and $13 \mathrm{~g} \mathrm{~kg}^{-1}$ phosphorus) was applied per hectare. Forage was implanted on red-yellow eutrophic soil with a clay texture with the following chemical characteristics: $\mathrm{pH}$ in $\mathrm{CaCl}_{2}, 6.3, \mathrm{P}$ (Mehlich): $21.2 \mathrm{mg} \mathrm{dm}^{-3} ; \mathrm{K}$ (Mehlich): $110 \mathrm{mmolc} \mathrm{dm}^{-3}$; $\mathrm{Ca}^{2+}\left(\mathrm{KCl} 1 \mathrm{~mol} \mathrm{~L}^{-1}\right)$ : $3.9 \mathrm{cmolc} \mathrm{dm}^{-3} ; \mathrm{Mg}^{2+}\left(\mathrm{KCl} 1 \mathrm{~mol} \mathrm{~L}^{-1}\right): 1.1 \mathrm{cmol}_{\mathrm{c}}$ 
$\mathrm{dm}^{-3} ; \mathrm{Al}^{3+}\left(\mathrm{KCl} 1 \mathrm{~mol} \mathrm{~L}^{-1}\right): 0.0$ cmolc $\mathrm{dm}^{-3}: \mathrm{H}+$ $\mathrm{Al}$ (calcium acetate $0.5 \mathrm{~mol} \mathrm{~L}^{-1}$ ): $1.2 \mathrm{cmolc} \mathrm{dm}^{-3}$ :

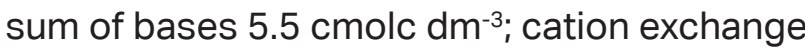
capacity: $6.7 \mathrm{cmolc} \mathrm{dm}^{-3}$ : V: $82 \%$.

After 90 days of growth, BRS capiaçu grass was cut approximately $15 \mathrm{~cm}$ from the ground manually using a forage cutter. Forage was chopped immediately after cutting in a shredder/chopper (JF, 40 P, Itapura, São Paulo, Brasil) adjusting particle size to $2 \mathrm{~cm}$. During ensiling, the average air temperature was 25 ${ }^{\circ} \mathrm{C}, 75 \%$ relative humidity and $15 \mathrm{~km} \mathrm{~h}^{-1}$ wind speed. On average, the height of the plants was 2.9 meters.
Two bacterial-enzymatic inoculants with different levels of enzyme complex were evaluated (Silotrato $^{\circledR}(5 \%)$ and Biotrato ${ }^{\circledR}$ (8\%)) and a silage control (without additive). A completely randomized design with eight replications was used. Liquid bacterialenzymatic inoculants were sprayed according to the manufacturer's recommendations ( $2 \mathrm{~g}$ product per ton of green forage mass; Table 1). All treatments received the same volume of drinking water at room temperature, without chlorine $\left(2 \mathrm{~mL} \mathrm{~kg}^{-1}\right)$.

\section{Table 1}

Levels of assurance of the enzymatic-bacterial inoculant used in the experiment

\begin{tabular}{|c|c|c|}
\hline Composition (cfu g ${ }^{-1}$ ) & Silotrato ${ }^{\circledR}$ & Biotrato ${ }^{\circledR}$ \\
\hline Enterococcus faecium (mín) & $1.0 \times 10^{10}$ & $1.0 \times 10^{10}$ \\
\hline Lactobacillus acidophilus & $1.0 \times 10^{10}$ & $1.0 \times 10^{10}$ \\
\hline Lactobacillus buchineri & $1.0 \times 10^{10}$ & $1.0 \times 10^{10}$ \\
\hline Lactobacillus curvatus & $1.0 \times 10^{10}$ & $1.0 \times 10^{10}$ \\
\hline Lactobacillus plantarum & $1.0 \times 10^{10}$ & $1.0 \times 10^{10}$ \\
\hline Lactococcus lactis & $1.0 \times 10^{10}$ & $1.0 \times 10^{10}$ \\
\hline Pediococcis acidilactici & $1.0 \times 10^{10}$ & $1.0 \times 10^{10}$ \\
\hline Propioni bacterium & $1.0 \times 10^{10}$ & $1.0 \times 10^{10}$ \\
\hline Enzyme complex & $5 \%$ & $8 \%$ \\
\hline
\end{tabular}

cfu - colony forming unit; Source: SLO Biotecnologia \& Agropecuária

(Source: http://www.sloagropecuaria.com.br/categoria/4/inoculantes.html).

For silage, Polyvinylchloride (PVC) experimental silos of known weight, $50 \mathrm{~cm}$ long and $10 \mathrm{~cm}$ in diameter were used. The bottom of the silos contained $10 \mathrm{~cm}$ of dry sand $(400 \mathrm{~g})$ which was separated from the forage by quantify the effluent produced. After complete homogenization of the forage, the resulting material was deposited in the silos and compacted with a wooden plunger. For each treatment, silage density was quantified (550 kg natural matter $\mathrm{m}^{-3}$ ) as recommended by Ruppel, Pitt, Chase, \& Galton (1995). After filling, silos were closed with PVC caps equipped with Bunsen valves, sealed with 
adhesive tape and weighed. Silos were stored at room temperature and opened 31 days after sealing.

DM losses from silages as gases and effluents were quantified by weight difference of ensiled mass according to Jobim, Nussio, Reis and Schmidt (2007). For effluent loss, equation 1 was used.

$$
\begin{gathered}
E=(P a b-P e n) /(M V f e) \\
\text { (Equation 1) }
\end{gathered}
$$

where:

E: effluent losses ( $\mathrm{kg} \mathrm{ton}^{-1}$ green mass); Pab: weight of the set (bucket + cap + wet sand + foam) at the opening (kg); Pen: weight of the set (bucket + cap + dry sand + foam) in the silage (kg); MVfe: silage green forage mass (kg).

DM losses as gases was calculated by the difference between the gross weight of the initial and final ensiled dry matter, in relation to the amount of ensiled DM, discounting the weight of the silo and dry sand set, according to the equation (2):

$$
\mathrm{G}=\left[(\mathrm{PCen}-\mathrm{Pen})^{*} \mathrm{MSen}\right]-[(\mathrm{PC} \text { ab- }
$$

Pen)*MSab] x $100\left[(\text { PCen }- \text { Pen })^{*}\right.$ MSen $]$ (Equation 2)

In which:

G: gas losses (\% DM); PCen: weight of the full bucket at sealing (kg); Pen: weight of the set (bucket + cap + dry sand + foam) in the silage (kg); MSen: forage dry matter content in silage; PCab: weight of full bucket at the opening (kg); MSab: forage dry matter content at opening. The DM recovery for each silo was calculated based on the initial and final weight and the DM contents of the forages and silages according to Jobim et al. (2007).

Aerobic stability was determined by placing a silage sample (approximately $3 \mathrm{~kg}$ ) fromeachsiloinanothersiloand keptinaroomat temperature $\left(24.5-25.5^{\circ} \mathrm{C}\right)$. Silage temperature was measured every hour using a data logger placed at the center of the mass for six days. Room temperature was also measured every hour by a data collector placed near the silos. The $\mathrm{pH}$ was also measured. The determination of $\mathrm{pH}$ was obtained by silage extract. The $\mathrm{pH}$ was measured with a potentiometer (Ak 90, Akso Measuring Instruments, São Leopoldo, RS, Brasil). Aerobic stability was defined as the number of hours that the temperature of the silage remained stable before increasing by more than $2{ }^{\circ} \mathrm{C}$ above ambient temperature.

The determination of ammonia nitrogen $\left(\mathrm{N}-\mathrm{NH}_{3}\right)$ and organic acids (Pryce, 1969) were obtained also by means of silage extract. Ammonia nitrogen $\left(\mathrm{N}-\mathrm{NH}_{3}\right)$ was measured according to Noel and Hambleton (1976). The volatile fatty acid contents were determined by liquid chromatography on UPLC (Shimadzu ${ }^{\circledR}$ Prominence System model 20A, Kyoto, Japan) equipped with UV-Vis detector adjusted to $210 \mathrm{~nm}$, automatic injector calibrated to $5 \mu \mathrm{L}$ sample volume and $300 \mathrm{x}$ $7.8 \mathrm{~mm}$ Rezex ${ }^{\mathrm{TM}}$ ROA-Organic Acid+column (Phenomenex) maintained at $60{ }^{\circ} \mathrm{C}$ in oven chamber. The analytes were eluted with 2.5 $\mathrm{mM} \mathrm{H}_{2} \mathrm{SO}_{4}$ at a flow rate of $0.6 \mathrm{~mL} \mathrm{~min}^{-1}$. External standards were used for quantitative calibration.

A portion of the silages was pre-dried in a forced ventilation oven at $55^{\circ} \mathrm{C}$. Subsequently, all samples were ground in a knife mill with a 1 $\mathrm{mm}$ mesh sieve for laboratory analysis. Part of the samples were ground in a $2 \mathrm{~mm}$ mesh sieve for in vitro digestibility analysis. Samples were analyzed for dry matter content (INCT-CA G-001/1 and G-003/1), crude protein (INCTCA N-001/1), ether extract (INCT-CA G-005/1), and ash (INCT-CA M-001/1), neutral detergent 
fiber (INCT-CA F-002/1) and acid detergent fiber (INCT-CA F-003/1), indigestible neutral detergent fiber (iNDF) (INCT-CA F-008/1), lignin (INCT-CA F-005/1) and non-fiber carbohydrates, according to Detmann et al. (2012). The content of total digestible nutrients (TDN) was estimated according to National Research Council [NRC] (2001) (Table 2).

\section{Table 2}

\section{Nutritional composition of forage before ensilage}

\begin{tabular}{|cc|}
\hline Item $\left(\mathrm{g} \mathrm{kg}^{-1}\right)$ & BRS capiaçu grass $90 \mathrm{~d}$ \\
\hline $\mathrm{pH}$ & 6.5 \\
Dry matter & 228.5 \\
Ash & 123.9 \\
\hline Crude protein & 78.4 \\
Ether extract & 9.3 \\
\hline Neutral detergent fiber & 729.0 \\
\hline Acid detergent fiber & 503.7 \\
Lignin & 57.5 \\
iNDF & 303.8 \\
\hline Total carbohydrates & 788.1 \\
\hline Non-fibrous carbohydrates & 59.1 \\
\hline Total digestible nutrients & 390.6 \\
\hline In vitro digestibility of DM & 772.2 \\
\hline In vitro digestibility of NDF & 673.3 \\
\hline In vitro digestibility of ADF & 466.0 \\
\hline
\end{tabular}

DM - Dry matter; NDF - neutral detergent fiber; ADF - Acid detergent fiber; iNDF- Indigestible neutral detergent fiber.

The in vitro digestibility of DM, organic matter, crude protein, neutral detergent fiber and acid detergent fiber were determined according to Tilley \& Terry (1963). The technique was modified according to Detmann et al. (2012) with the use of in vitro incubator Tecnal ${ }^{\circledR}$ (TE-150), using non-woven fabric (100 $\left.\mathrm{g} \mathrm{m}^{-2}\right)$ for making the incubation bag $(7.5 \times 7.5$ $\mathrm{cm})$, according to Valente et al. (2011).

Data were subjected to analysis of variance. The Shapiro-Wilk test and the Bartlett test were used to examine the normality of residuals and homoscedasticity of variance, respectively. Variables related to fermentation profile and nutritional values were analyzed according to the model:

$$
Y_{i j}=\mu+\operatorname{lno} o_{i}+e_{i j}
$$

In which:

$Y_{i j}=$ observation regarding the inoculant treatment (Ino) "i" in repetition " $\mathrm{j}$ " with $\mathrm{j}=1,2, \ldots, 8$;

$\mu=$ constant associated with all the observations;

$$
\text { Inoi }=\text { Effect of inoculant " } \mathrm{i} \text { ", with } \mathrm{i}=1 \text {, }
$$

2 e3; 
$\mathrm{e}_{\mathrm{ij}}=$ experimental error associated with plots that hypothetically have normal distribution with zero mean and variance $\delta_{2}$.

Mean values for inoculants were compared by the Student Newman Keuls test (SNK) with $\alpha=0.05$.

The aerobic stability of the silage was analyzed following a completely randomized design in split plots with three treatments (plots) and seven times after opening (subplots) with eight replications. The following statistical model was used:

$$
Y_{i j k}=\mu+\operatorname{Ino}_{i}+e_{i j}+\operatorname{Timek}+\operatorname{Ino}_{i} \times \operatorname{Time}_{k}+e_{i j k}
$$

In which:

$Y k(i j)=$ The observation referring to time "k" (subplot) in inoculant "i" (plot) in repetition "j";

$\mu=$ constant associated with all observations;

Inoi = Effect of inoculant "i", with $i=1,2$ and 3;

eij $=$ experimental error associated with plots that hypothetically have normal distribution with zero mean and variance $\delta 2$;

Time $k=$ Effect of time after opening the silage " $k$ ", with $k=1,2,3,4,5,6$ e 7 ;
Ino $x$ Time $=$ Effect of interaction between inoculant " $\mathrm{i}$ " with time after opening the silage "j";

eijk = experimental error associated with all observations that, by hypothesis, have normal distribution with zero mean and variance $\delta_{2}$.

Mean values for inoculants, times after opening and their interactions were subjected to $F$ test and when significant, the inoculants and interactions were compared using the Student Newman Keuls test (SNK). The comparisons between times after opening were performed by decomposing the sum of squares into orthogonal linear contrasts and quadratic effects. For all statistical procedures, $\alpha=0.05$ was used as the maximum tolerable limit for type I error.

\section{Results and Discussion}

There was no interaction between treatments and times after opening the silo on $\mathrm{pH}$ values $(\mathrm{P}=0.79)$. In relation to bacterialenzymatic inoculants, the silage $\mathrm{pH}$ in silage without additive (mean of 6.00 ) was $21.66 \%$ and $16.16 \%$ higher in relation to silage with $5 \%$ (Silotrato ${ }^{\circledR}$ ) and 8\% (Biotrato ${ }^{\circledR}$ ) enzyme complex $(P<0.01$; Figure 1), respectively. 


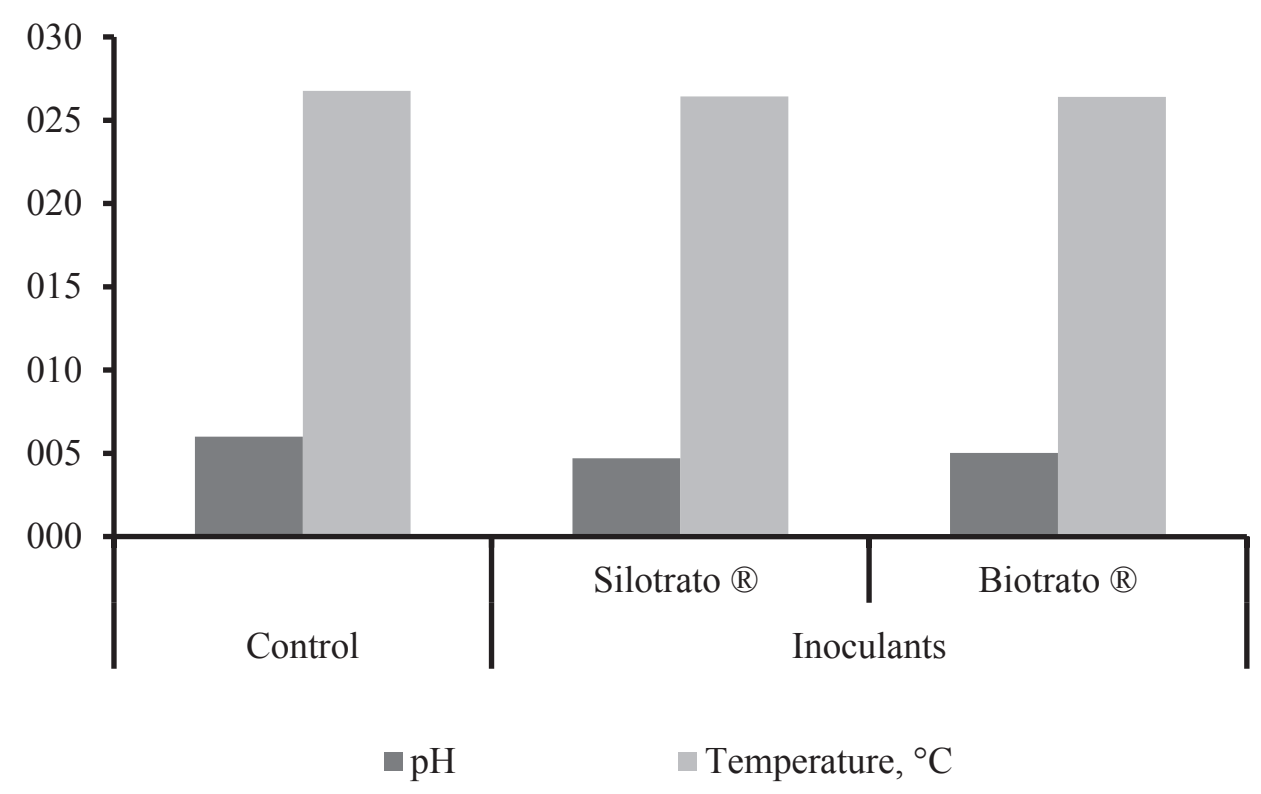

Figure 1. Mean values of $\mathrm{pH}$ and temperature during aerobic stability of BRS capiaçu grass silage associated with different bacterial-enzymatic inoculants (effects of treatments for $\mathrm{pH}$ and temperature $(\mathrm{P}<0.01))$.

There was a difference between the times after opening the silo on $\mathrm{pH}(\mathrm{P}<0.01$; Figure 2). As the time after opening increased, there was a linear increase in $\mathrm{pH}$ value, from 3.16 at the time of opening to 7.12 after 144 hours opening.

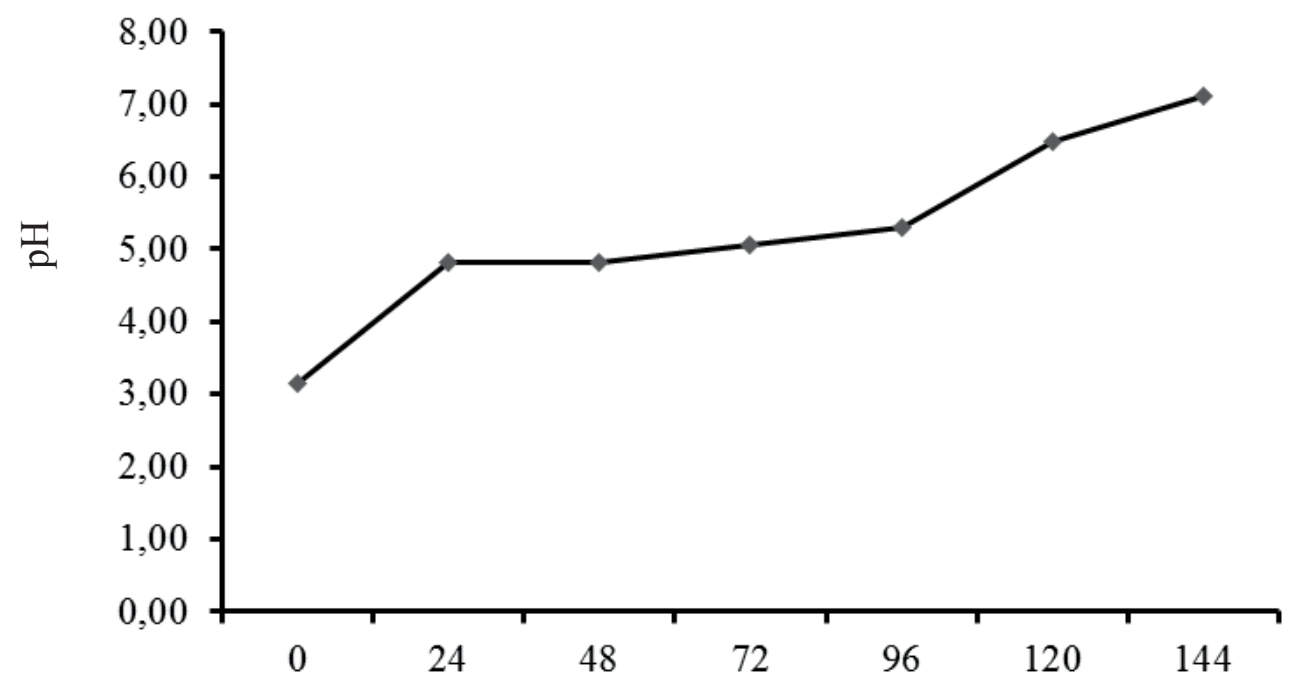

Exposure time to air (hours)

Figure 2. Mean values of pH during aerobic stability of BRS capiaçu grass silages at different times after opening (interaction between treatments and times after opening: $P=0.79$ ). 
There was interaction between treatments and times after opening on the silage temperature $(P<0.01$; Figure 3$)$. Differences between treatments were found at 24, 48, 72 and 144 hours after opening, with the highest temperatures verified in the control silage in relation to the other treatments. Between the times after opening, it was found that the control silage showed a break of aerobic stability (silage temperature $2{ }^{\circ} \mathrm{C}$ above the ambient temperature of 25 ${ }^{\circ} \mathrm{C}$ ) after 72 hours. In the studied times, there was no break of stability in the silages treated with different levels of bacteria and fibrolytic enzymes until 144 hours after opening.

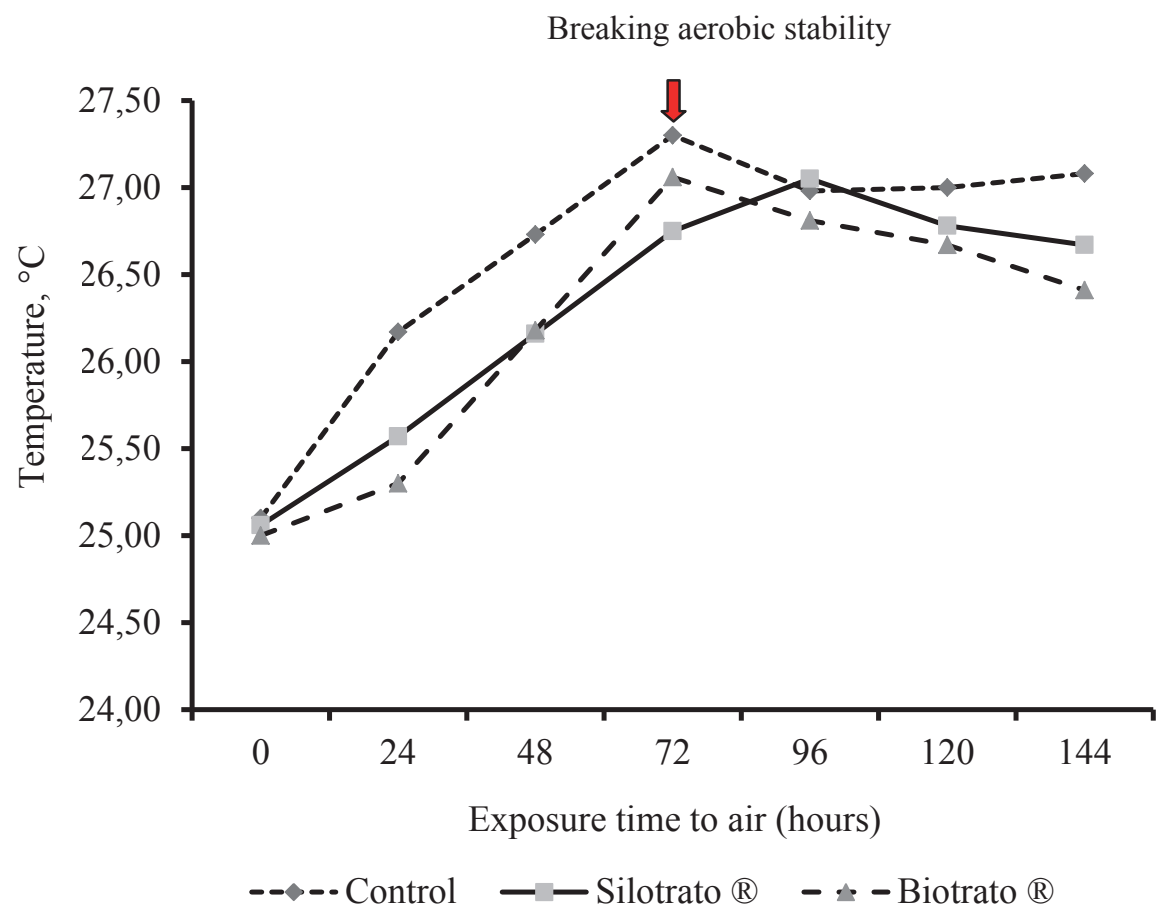

Figure 3. Temperature of BRS capiaçu grass silage associated with different bacterial-enzymatic inoculants at different times after opening (interaction between treatments and times after opening: $P<0.01$ ).

There was no difference between treatments on $\mathrm{pH}(\mathrm{P}=0.08)$, lactic acid $(\mathrm{P}=$ $0.08)$ and acetic acid $(P=0.64)$ at the time of opening, with mean values of $3.11,47.31 \mathrm{~g}$ $\mathrm{DM}^{-1}$ and $11.19 \mathrm{~g} \mathrm{DM}^{-1}$, respectively. There was a higher concentration of butyric acid in the control silage compared with the silage with Silotrato ${ }^{\circledR}$. There was a higher concentration of ammonia nitrogen in the control silage compared with the silage with inoculants. The control silage and silage treated with Biotrato ${ }^{\circledR}$ presented effluent losses ( $P=0.05$ ) 13.99\% higher than silage with Silotrato ${ }^{\circledR}$ (Table 3). There was greater gas loss $(P<0.01)$ in the control silage (without additive). The greatest recovery of dry matter $(P<0.01)$ was observed in the silage inoculated with Silotrato ${ }^{\circledR}$. The silage containing inoculant Biotrato ${ }^{\circledR}$ presented dry matter recovery $4.90 \%$ higher than control silage (mean of $85.47 \%$ ). 
Table 3

Fermentation profile of BRS capiaçu grass silage containing different bacterial-enzymatic inoculants

\begin{tabular}{|c|c|c|c|c|c|}
\hline \multirow{2}{*}{ Item } & \multirow{2}{*}{ Control } & \multicolumn{2}{|c|}{ Inoculants } & \multirow{2}{*}{ SEM } & \multirow{2}{*}{ P-value } \\
\hline & & Silotrato ${ }^{\circledR}$ & Biotrato ${ }^{\circledR}$ & & \\
\hline $\mathrm{pH}^{1}$ & 3.08 & 3.03 & 3.23 & 0.04 & 0.08 \\
\hline Ammoniacal nitrogen, \% TN & $5.25 a$ & $4.57 \mathrm{~b}$ & $4.12 \mathrm{~b} \mathrm{a}$ & 0.22 & $<0.01$ \\
\hline Lactic acid, g DM-1 & 45.30 & 49.34 & 47.20 & 1.15 & 0.08 \\
\hline Acetic Acid, g DM-1 & 10.37 & 11.88 & 11.31 & 0.86 & 0.64 \\
\hline Butyric acid, g DM"-1 & $0.90 \mathrm{a}$ & $0.62 b$ & $0.77 \mathrm{ab}$ & 0.07 & 0.04 \\
\hline Effluents losses, kg GM t-1 & $113.73 \mathrm{a}$ & $93.94 \mathrm{~b}$ & $104.71 \mathrm{a}$ & 5.35 & 0.05 \\
\hline Gas losses, \% DM & $13.35 \mathrm{a}$ & $7.33 \mathrm{~b}$ & $9.29 \mathrm{~b}$ & 0.67 & $<0.01$ \\
\hline Dry matter recovery, \% & $85.47 \mathrm{c}$ & $92.66 \mathrm{a}$ & $89.88 \mathrm{~b}$ & 0.68 & $<0.01$ \\
\hline
\end{tabular}

$\mathrm{pH}$ - values at opening; NT - Total nitrogen; GM - Green matter; $\mathrm{t}$ - tons; DM - Dry matter; SEM - Standard error of the mean; P - Probability. Means followed by different letters differ $(P<0.05)$ by the Student Newman Keuls test at the $5 \%$ probability level.

There was no difference between treatments for any of the chemical composition variables ( $P=0.86$; Table 4). Mean values of
DM, crude protein, neutral detergent fiber and total digestible nutrients were $22.31 \%, 6.65 \%$, $71.15 \%$ and $42.07 \%$, respectively.

Table 4

Chemical composition of BRS capiaçu grass silage containing different bacterial-enzymatic inoculants

\begin{tabular}{|cccccc}
\hline \multirow{2}{*}{ Item (\%) } & Control & \multicolumn{2}{c}{ Inoculants } & \multirow{2}{*}{ SEM } & P-value \\
\cline { 3 - 4 } & & Silotrato ${ }^{\circledR}$ & Biotrato ${ }^{\circledR}$ & & \\
Dry matter & 21.39 & 23.94 & 21.58 & 0.92 & 0.12 \\
Ash & 12.23 & 11.94 & 11.22 & 0.48 & 0.34 \\
\hline Crude protein & 6.88 & 6.58 & 6.49 & 0.18 & 0.31 \\
\hline Ether extract & 1.92 & 1.92 & 2.14 & 0.10 & 0.24 \\
\hline Neutral detergent fiber & 70.45 & 70.62 & 72.4 & 0.72 & 0.13 \\
\hline Acid detergent fiber & 47.34 & 47.95 & 49.88 & 0.75 & 0.06 \\
\hline Lignin & 8.28 & 7.96 & 8.94 & 0.62 & 0.54 \\
\hline Total carbohydrates & 78.94 & 79.55 & 80.13 & 0.51 & 0.29 \\
\hline Non-fibrous carbohydrates & 8.49 & 8.92 & 7.73 & 0.91 & 0.65 \\
\hline Total digestible nutrients & 42.17 & 42.19 & 41.85 & 0.49 & 0.86 \\
\hline
\end{tabular}

SEM - Standard error of the mean; P - Probability. 
The use of inoculants did not alter the in vitro digestibility of $D M(P=0.14)$, organic matter $(P=0.11)$, crude protein $(P=0.10)$, neutral detergent fiber $(P=0.32)$ and acid detergent fiber $(P=0.12)$ (Table 5). The control silage showed a higher indigestible fraction of DM $(P=0.05)$, neutral detergent fiber $(P=0.02)$ and acid detergent fiber $(P=0.04)$ compared to silages treated with inoculants.

\section{Table 5}

Digestibility and indigestible fraction of BRS capiaçu grass silage containing different bacterialenzymatic inoculants

\begin{tabular}{|c|c|c|c|c|c|}
\hline \multirow{2}{*}{ Item (\%) } & \multirow{2}{*}{ Control } & \multicolumn{2}{|c|}{ Inoculants } & \multirow{2}{*}{ SEM } & \multirow{2}{*}{ P-value } \\
\hline & & Silotrato ${ }^{\circledR}$ & Biotrato ${ }^{\circledR}$ & & \\
\hline \multicolumn{6}{|c|}{ In vitro digestibility } \\
\hline Dry matter & 73.94 & 74.71 & 77.15 & 1.15 & 0.14 \\
\hline Organic matter & 71.66 & 74.17 & 75.59 & 1.29 & 0.11 \\
\hline Crude protein & 63.90 & 66.23 & 75.40 & 3.84 & 0.10 \\
\hline Neutral detergent fiber & 67.25 & 69.27 & 69.85 & 1.24 & 0.32 \\
\hline Acid detergent fiber & 47.21 & 49.77 & 49.81 & 0.99 & 0.12 \\
\hline \multicolumn{6}{|c|}{ Indigestible fraction } \\
\hline Dry matter & $40.81 \mathrm{a}$ & $38.44 b$ & $37.25 b$ & 0.98 & 0.05 \\
\hline Neutral detergent fiber & $33.93 \mathrm{a}$ & $31.84 \mathrm{~b}$ & $30.11 b$ & 0.9 & 0.02 \\
\hline Acid detergent fiber & $25.09 a$ & $23.01 \mathrm{~b}$ & $21.56 b$ & 0.93 & 0.04 \\
\hline
\end{tabular}

SEM - Standard error of the mean; P - Probability. Means followed by different letters differ $(P<0.05)$ by the Student Newman Keuls test at the $5 \%$ probability level.

Several factors together and/or alone are used to classify silage as good or bad when considering the fermentation profile. Normally, good silage should have a $\mathrm{pH}$ value ranging from 3.5 to 4.60 for grasses, butyric acid content less than $10 \mathrm{~g} \mathrm{~kg}^{-1} \mathrm{DM}$, ammonia nitrogen below $10 \%$ total nitrogen and high dry matter recovery (Borreani, Tabacco, Schmidt, Holmes, \& Muck, 2018; Kung, Shaver, Grant, \& Schmidt, 2018). Therefore, in general, BRS capiaçu grass silages were well preserved. However, it was verified that among the treatments, the control silage (without additive) presented a higher concentration of butyric acid and gas losses and less recovery of DM in relation to silages treated with inoculants containing fibrolytic enzymes and lactic acid bacteria.

Regarding the $\mathrm{pH}$ of the silages after silo opening, there was no difference between treatments due to the presence of epiphytic microorganisms that favor the decline in $\mathrm{pH}$ due to the production of organic acids, especially lactic acid. Amaral et al. (2020) managed to isolate 65 natural strains of bacteria in the BRS capiaçu silage with the ability to reduce the $\mathrm{pH}$, which justifies the results of this research for the control silage. 
In this sense, the use of inoculants in silage is justified by introducing selected homoheterofermentative bacteria to quickly reduce the ensiled mass, favoring better preservation. In this research, silage containing the inoculant Silotrato ${ }^{\circledR}$ presented lower concentration of butyric acid and losses by effluents and greater recovery of dry matter in relation to the other treatments. This is justified because the $\mathrm{pH}$ of the mass was reduced due to the production of lactic acid in short time, inhibiting the growth of Clostridium bacteria responsible for synthesis of butyric acid and aerobic bacteria, improving the fermentation quality of the silage (Tian et al., 2014).

Regarding the aerobic stability of silages, it was found that the $\mathrm{pH}$ and temperature of silages 144 hours after opening were higher in the control silage. This is interesting when it comes to using inoculants in silage. It was found that after opening, there was activity of aerobic bacteria that began to ferment silage nutrients justifying the increase in temperature. Consequently, the break in aerobic stability of the control silage occurred early (72 hours) after opening. The acetic acid produced by heterofermentative bacteria, such as Lactobacillus spp., is responsible for preserving the silage for a longer after opening, inhibiting the growth of undesirable microorganisms in the silage. However, there was no difference between treatments for the values of acetic acid in the silage (mean of $11.19 \mathrm{~g} \mathrm{~kg}^{-1} \mathrm{DM}$ ). In this way, fibrolytic enzymes had no effect on fiber degradation to increase the concentrations of soluble sugars and improve the production of acetic and lactic acid. In this situation, Zhang, $\mathrm{Li}$, Zhao and Yu (2016) suggested that soluble carbohydrates present in the ensiled mass were sufficient for the fermentation process, which justifies the results of this research.
In a research with the Napier cultivar (Pennisetum purpureum Schum.), Bureenok et al. (2019) also did not observe changes in the lactic acid synthesis when using inoculant containing fibrolytic enzymes and lactic acid bacteria in ensiling. Previous studies have suggested that the addition of fibrolytic enzymes may improve the quality of fermentation due to degradation of the fiber fraction of tropical forage silages (Khota et al., 2016; Li, Zhou, Zi, \& Cai, 2017; Wang et al., 2019). This result was not evident in this research. However, Bureenok et al. (2019) highlighted the lack of effect can be attributed to enzyme activity that is dependent on temperature and pH. According to Chung et al. (2012), fibrolytic enzymes such as cellulase require a $\mathrm{pH}$ of 5.06.5 and temperature ranging from $39^{\circ} \mathrm{C}$ to 50 ${ }^{\circ} \mathrm{C}$ for adequate activity. Therefore, the rapid drop in $\mathrm{pH}$ of the BRS capiaçu grass treated with inoculant after ensiling may have inhibited cellulase activity as reported by Khota, Pholsen, Higgs and Cai (2017) and Bureenok et al. (2019).

The use of Silotrato $^{\circledR}$ and Biotrato ${ }^{\circledR}$ in the silage of BRS capiaçu grass did not change the chemical composition and digestibility of silage. However, inoculants reduced the insoluble fraction of $\mathrm{DM}$, neutral detergent fiber and acid detergent fiber. This can be justified by linked the ester-type bonds present in the cell wall of the grass with the use of inoculants. Although it seems to have activity limited by fibrolytic enzymes, this is an interesting finding of this research. The content of iNDF in feed for ruminants is pointed out by Detmann, Valente, Batista, \& Huhtanen (2014) as one of the main factors affecting dry matter intake and animal performance. In this study, the use of inoculants reduced the insoluble fiber content of the silage by 
9.55\%. However, the temperature and $\mathrm{pH}$ drop over the days in fermentation may have inhibited greater results of enzymatic activity, explaining the lack of effect on in vitro digestibility (Colombatto, Mould, Bhat, Phipps, \& Owen, 2004). However, in this research, the temperature was not expected to affect the enzyme activity because the silos were kept at room temperature $\left(25^{\circ} \mathrm{C}-37^{\circ} \mathrm{C}\right)$. Even at room temperature, Khota et al. (2017) evaluated sorghum silage inoculated with fibrolytic enzymes and lactic acid bacteria and did not find changes in the nutritional value of silages, justifying the enzyme inhibition by temperature. In Napier grass silage, Bureenok et al. (2019) did not observe the effect of fibrolytic enzymes associated with lactic acid bacteria on the potential degradability of DM and digestibility of organic matter.

\section{Conclusion}

During ensiling BRS capiaçu grass, the use of lactic-acid bacteria containing 5\% fibrolytic enzymes (Silotrato ${ }^{\circledR}$ ) is recommended as they reduce fermentation losses and the indigestible fraction of silages.

\section{Acknowledgments}

The authors are grateful to the Research Support Foundation of the State of Minas Gerais (FAPEMIG); Unimontes; National Institute of Science and Technology (INCT); and the National Council for Scientific and Technological Development (CNPq). This study was funded in part by the Coordination for the Improvement of Higher Education Personnel Brazil (CAPES) - Financial Code 001.

\section{References}

Amaral, R. C., Carvalho, B. F., Costa, D. M., Morenz, M. J. F., Schwan, R. F., \& Ávila, C. L. S. (2020). Novel lactic acid bacteria strains enhance the conservation of elephant grass silage cv. BRS capiaçu. Animal Feed Science and Technology, 264(1), 1-12.doi: 10.1016/j.anifeedsci.2020.114472

Borreani, G., Tabacco, E., Schmidt, R. J., Holmes, B. J., \& Muck, R. E. (2018).Silage review: factors affecting dry matter and quality losses in silages. Journal of Dairy Science, 101(1), 3952-3979. doi:10.3168/jds.201713837

Bureenok, S., Langsoumechai, S., Pitiwittayakul, N., Yuangklang, C., Vasupen, K., Saenmahayak, B., \&Schonewille, J. T. (2019). Effects of fibrolytic enzymes and lacticacid bacteria on fermentation quality and in vitro digestibility of Napier grass silage. Italian of Journal Animal Science, 18(1), 1438-1444. doi: 10.1080/ 1828051X.2019.1681910

Chung, Y. H., Zhou, M., Holtshausen, L., Alexander, T. W., McAllister, T. A., Guan, L. L.,...Beauchemin, K. A. (2012). A fibrolytic enzyme additive for lactating Holstein cow diets: ruminal fermentation, rumen microbial populations, and enteric methane emissions. Journal of Dairy Science, 95(3), 1419-1427. doi: 10.3168/ jds.2011-4552

Colombatto, D., Mould, F. L., Bhat, M. K., Phipps, R. H., \& Owen, E. (2004).In vitro evaluation of fibrolytic enzymes as additives for maize (Zea mays L.) silage. Animal Feed Science and Technology, 111(1), 111-128. doi: 10.1016/j.anifeedsci.2003.08.011 
Desta, S. T., Yuan, X., Li, J., \& Shao, T. (2016). Ensiling characteristics, structural and nonstructural carbohydrate composition and enzymatic digestibility of napier grass ensiled with additives. Bioresource Technology, 221(9), 447-454.doi: 10.1016/ j.biortech.2016.09.068

Detmann, E., Souza, M. A., Valadares Filho, S. C., Queiroz, A. C., Berchielli, T. T., Saliba, E. O. S.,... Azevedo, J. A. G. (2012). Métodos para análise de alimentos. Visconde do Rio Branco, MG: Suprema.

Detmann, E.,Valente, E. E. L., Batista, E. D., \& Huhtanen, P. (2014). An evaluation of the performance and efficiency of nitrogen utilization in cattle fed tropical grass pastures with supplementation. Livestock Science, 162(1), 141-153.doi: 10.1016/j. livsci.2014.01.029

Jobim, C. C., Nussio, L. G., Reis, R. A., \& Schmidt, P. (2007). Avanços metodológicos na avaliação da qualidade de forragem conservada. Revista Brasileira de Zootecnia, 36(1), 101-119. doi: 10.1590/ S1516-35982007001000013

Khota, W., Pholsen, S., Higgs, D., \& Cai, Y. (2016). Natural lactic acid bacteria population of tropical grasses and their fermentation factor analysis of silage prepared with cellulose and inoculant. Journal of Dairy Science, 99(12), 9768-9781. doi: 10.3168/ jds.2016-11180

Khota, W., Pholsen, S., Higgs, D., \&Cai, Y. (2017). Fermentation quality and in vitro methane production of sorghum silage prepared with cellulase and lactic acid bacteria. Asian-Australasian Journal of Animal Sciences, 30(11), 1568-1574. doi: 10.5713/ajas.16.0502
Kung, L., Jr.,Shaver, R. D., Grant, R. J., \& Schmidt, R. J. (2018).Silage review: interpretation of chemical, microbial, and organoleptic components of silages. Journal of Dairy Science, 101(1), 4020-4033. doi: 10.3168/ jds.2017-13909

Li, M., Zhou, H., Zi, X., \& Cai, Y. (2017). Silage fermentation and ruminal degradation of stylo prepared with lacticacid bacteria and cellulase. Animal Science Journal, 88(10), 1531-1537. doi: 10.1111/asj.12795

Monção, F. P., Costa, M. A. M. S., Rigueira, J. P. S., Moura, M. M. A., Rocha, V. R., Jr.,Mesquita, V. G.,... Chamone, J. M. A. (2019a). Yield and nutritional value of BRS Capiaçu grass at different regrowth ages. Semina: Ciências Agrárias, 41(5), 745-755. doi: 10. 5433/1679-0359.2019v40n5p2045

Monção, F. P., Costa, M. A. M. S., Rigueira, J. P. S., Sales, E. C. J.,Leal, D. B., Silva, M. F. P.,... Rocha, V. R., Jr.(2019b). Productivity and nutritional value of BRS capiaçu grass (Pennisetum purpureum) managed at four regrowth ages in a semiarid region. Tropical Animal Health and Production, 52(1), 235-241. doi: 10.1007/s11250-019 $-02012-y$

National Research Council (2001). Nutrient requirements of dairy cattle (7nd rev. ed.).Washington, DC: National Academy Press.

Noel, R. J. \& Hambleton, L. G. (1976). Collaborative study of a semiautomated method for determination of crude protein in animal feeds. Journal of the AOAC, 59(1)134-140.

Pereira, A. V., Lédo, F. J. S., \& Machado, J. C. (2017). BRS Kurumi and BRS capiaçu - new elephant grass cultivars for grazing and 
cut-and-carry system. Crop Breeding and Applied Biotechnology, 17(1), 59-62. doi: 10.1590/1984-70332017v17n1c9

Pryce, J. D. (1969). A modification of BarkerSummerson method for the determination of lactic acid. Analyst, 94(1), 1151-1152. doi: 10.1039/AN9699401151

Ruppel, K. A., Pitt, R. E., Chase, L. E., \& Galton, D. M. (1995). Bunker silo management and its relationship to forage preservation on dairy farms. Journal of Dairy Science, 78(1), 141-153. doi: 10.3168/jds.S00220302(95)76624-3

Sun, Q., Gao, F., Yu, Z.,Tao, Y., Zhao, S., \& Cai, Y. (2012). Fermentation quality and chemical composition of shrub silage treated with lactic acid bacteria inoculants and cellulose additives. Animal Science Journal, 83(4), 305-309. doi: 10. 1111/j.1740-0929.2011.00962.x

Tian, J.,Yu, Y., Yu, Z., Shao, T., Na, R., \& Zhao, M. (2014). Effects of lactic acid bacteria inoculants and cellulose on fermentation quality and in vitro digestibility of Leymus chinensis silage. Grassland Science, 60(4), 199-205. doi: 10.1111/grs.12059
Tilley, J. M. A., \& Terry, R. A. (1963).A twostage technique for the in vitro digestion of forage crops. Journal of the British Grassland Society, 18(2), 104-111. doi: 10. 1111/j.1365-2494.1963.tb0033 5.x

Valente, T. N. P., Detmann, E.,Queiroz, A. C., Valadares, S. C., Fo., Gomes, D. I., \& Filgueiras, J. F. (2011). Evaluation of rumen degradation profiles of forages using bags made from different textiles. Revista Brasileira de Zootecnia, 40(11), 25652573. doi: 10.1590/S1516-35982011001 100039

Wang, S., Guo, G., Li, J., Chen, L., Dong, Z., \& Shao, T. (2019).Improvement of fermentation profile and structural carbohydrate compositions in mixed silages ensiled with fibrolytic enzymes, molasses and Lactobacillus plantarum MTD1. Italian Journal of Animal Science, 18(1), 328-335. doi: 10.1080/1828 051X.2018.1528899

Zhang, Q., Li, X., Zhao, M., \& Yu, Z. (2016). Lactic acid bacteria strains for enhancing the fermentation quality and aerobic stability of Leymus chinensis silage. Grass and Forage Science, 71(3), 472-481. doi: 10.11 $11 /$ gfs. 12190 
